\title{
The Meaning of Public Relations in the Indonesian Government Research Institutions
}

\author{
Dyah Rachmawati Sugiyanto $^{1}$, Suwandi Sumartias ${ }^{2,}$ Neni Yulianita ${ }^{3}$, Lukiati \\ Komala $^{4}$ \\ \{. dyah.humas@gmail.com ${ }^{1}$, wandi_sumartias@ yahoo.com ${ }^{2}$, yulianita.neni@gmail.com ${ }^{3}$, \\ lukiatikomala@gmail.com ${ }^{4}$ \} \\ ${ }^{1,2,3,4}$ Universitas Padjadjaran, Indonesia
}

\begin{abstract}
Public relations has different meanings among Government Public Relations officials. This study discusses the meaning of Government Public Relations in research institutions. Research institutes became the place of this research because their Public Relations faced obstacles in conveying popular scientific messages to the public. Nine informants from this study were Structural and Functional Public Relations Officers. This study uses constructivist paradigms, phenomenological theories, and qualitative methods. This study concludes that Government Public Relations officials at research institutions interpret Public Relations as communicators of educational messages and institutional communicators.
\end{abstract}

Keywords: Phenomenology, Government Public Relations, Construction Meaning

\section{Introduction}

Government public relations in Indonesia has experienced many developments. The history of government Public Relations (PR) notes that before the term PR emerged, in Indonesia the term 'relationship with the people' was first known. [1] This term began to be introduced along with the formation of the Indonesian government which declared independence on August 17, 1945. PR began to be known at the corporate level starting in the 1950s. At that time, 'Pertamina', which at that time was called the State Petroleum Company, already had a division called Government and Community Relations or abbreviated as 'Hupmas'. Another note states, the formation of PR was also carried out at the Indonesian National Police in 1951. In 1955-1959, the part of relations with the people was still a propaganda tool for the new government. In 1959-1964 there was a systematic pattern of coordination between State elements both formal and informal in explaining policy and information to the people. Furthermore, on March 13, 1971 the structure and tasks of the Government Public Relations (GPR) Coordinating Board (Bakohumas) were determined. A year after that was born the Public Relations Association (Perhumas) on 15 December 1972. Starting in 1995 many Public Relations forums sprang up, both among starred hotels, SOEs, and universities. [2]

During the reform period, in 2003 the first functional career path was born for civil servants, named Public Relations. The birth of Public Relations Institution seems to be a milestone in the development of public relations government. Furthermore, on August 27 
2015 was a historic date for Indonesian Public Relations Functional officials because on that date a professional public relations functional organization (non-structural) was born, named the Indonesian Public Relations Association (Iprahumas). Furthermore, in October 2015 through the Ministry of Communication and Informatics opened up opportunities for the public with certain requirements to become Government Public Relations Agents. GPR Agents works from the beginning of 2016 at the Ministry. At the same time the SOE (StateOwned Enterprises) task force was formed in order to respond to the dynamics of communication and social changes that occur, especially at the national level. [3]

GPR, in principle, carry out the same functions and roles as other public relations in general. But there are things that distinguish and become the characteristics of GPR. Government public relations must understand the limitations set in a number of government regulations and policies, as well as on work processes that are often hampered by bureaucratic culture. Performance of GPR also becomes difficult to increase. Based on the phenomenological approach, the typical functions of GPR are innovators, early adopters, influencers, and evolving storytellers. [4]

PR is a leadership and management function that helps achieve an organization's goals, helps define philosophy, and helps facilitate organizational change. PR practitioners communicate with all relevant internal and external communities to develop positive relationships and create consistency between organizational goals and community expectations. They also develop, implement, and evaluate organizational programs that promote the exchange of influence and understanding between organizational and community constituents. [5]

Based on this, an idea emerged about the working principle of the GPR is speed in capturing issues that are circulating in the public, able to penetrate the majority and public resistance by managing public opinion, and able to create meaning. The way the GPR works ideally is to form and maintain public trust, set the agenda setting, and be a source of accurate and trusted information.

In accordance with the focus of this research, this article highlights the GPR in research institutions. There is a common problem that is most fundamental, namely the challenge of managing scientific information so that it can be well received by the public. When informing the results of research researchers, for example. PR in government research institutes often have difficulty translating scientific terms into popular languages.

In social constructivism [6], individuals try to understand the world in which they live and work. They develop subjective meanings from their experiences, meanings directed at certain objects or certain objects. These meanings are diverse, prompting the researcher to seek more diverse views rather than narrowing them down to a small number of categories or ideas. The aim of the research, therefore, is to lean as much as possible on the views of the participants about certain situations. Often these subjective meanings are negotiated socially and historically. In translating scientific terms into popular languages, PR in government research institutes of social construction is based on knowledge, experience, and technological development.

Thus, the self-concept of a PR professional can be seen from his ability to analyze the situation, design, implement, and measure the effectiveness of communication programs carried out where he works. In addition, professional PR are people who have high maturity, those who can understand and accept their weaknesses and strengths. At the same time public relations professionals can also understand and consider the impact of their communication.

The professional PR self-concept as emphasized by Littlejohn that "The concept of self, which is so important in symbolic interactionism, has been the chief concern of Rom Harre 
(1979) in most of his theoretical work. Harre says that like any other experience, the self is structured by a personal theory. The self consistency of a set of elements that can be viewed spatially along three dimensions: display, realization, and agency. Display, whether an aspect of the self is displayed publicly or remains private. Realization, or source - the degree to which some features of the self are believed to come from within the individual or a group. Agency, is the degree of active power attributed to the self. "[7]

The statement above implies that in self-concept there are three elements that construct. First is personality. Second, the influence of groups / environment, and third is the effort of existence. The result of the construction of the meaning of GPR in a social context is that it is a work unit, management function, public servant, innovator, communicator as well as communicant, and professional. Whereas in a personal context, government public relations is a public relations institution that has the potential to become a GPR professional. The meaning constructed is summarized in what is expressed [8] that the public function of PR in the social system, namely maintaining good communication, serving public's interest, and maintaining good moral and manner. Similarly, what Griffin said, that "The core assumption of constructivism is that" persons make sense of the world through systems of personal constructs. Constructed are the cognitive templates or stencils we fit over reality to bring order to our perceptions. "[9]

The awareness of a PR to the PR profession by feeling inseparable from an organization. PR is very broad in scope. Research institute public relations must communicate the results of research so that it can truly be utilized maximally by the community. PR work shows the performance of the institution to be known and trusted by the public and the government. PR in government research institutes manage science and technology information to arrive and are well received by the public. To gain public trust, according to the private sector lies in the Profit. GPR think what it is doing is promoting community welfare, the ideals of community institutions.

In a research institution, a PR must convince himself that the results of research must be known by the public. A PR Officer is not required to be able to speak to the public, but more than that. PR in government research institutes must know technical things. For example, if you want to develop rockets, satellites, aviation, space, inevitably have to learn from abroad.

Public Relations conduct public education, dissemination (conveying to users of technology in the field regarding publications for the public). He assumed that there was a role for cooperation in everything that was done by PR. PR means how you convey information that should be conveyed to the public. PR is the mouthpiece of an institution. Representatives speak it must be PR. Not that other people should not talk, but as long as coordinating with PR means that there are no problems. This means that PR has the role to coordinate. So the information released is information that is expected to be a solution. In this case, Public Relations is the spokesman. If they ask, we answer. We feed if they ask. Thus, PR in research institutions has been interpreted as an information coordinator who is also a manager and conveyor of popular science information. As a PR official, he can communicate with people, can go anywhere, various characters can also understand people. PR Officer as a person who must have a creative and imaginative soul. Besides through the media in question, PR need to introduce government research institutions in various forums.

Furthermore, PR must convey what is happening in our institutions to the outside and we observe what PR provides input that government research institutions can provide input and what will contribute. The decision remains in the leadership. Ideally, much of their work is focused on developing recommendations for communication steps and considerations before the policy is decided. 
PR personnel must be energetic, become movers and boosters, learn a lot, write a lot, appear a lot, be good at communicating with journalists, hang out with public relations people, be given the opportunity to watch activities in work units, close to the leadership, but too close and not good either. PR The government is always bureaucratic, must know the official rules. PR needs to be supported with facilities such as infrastructure, bonuses, benefits, and so on.

PR must be able to summarize, resume diverse research, then we must choose some that have a positive impact on the public. In carrying out the mission of the organization, from the statement below the researcher analyzes that public relations activities can be carried out by anyone, with certain conditions that is after being equipped with the knowledge and skills as a PR officer.

In general, PR activities tend to be tasked with making the institution's image more positive. To get to professionalism, PR staff development is needed. The most important training is writing, speaking / communicating. The approach to improving quality is still in conflict with the budget. PR program's budget in research institutions are very limited. The socialization that is often followed is free. Another problem is facing senior staff. In a government institution tends to occur unprofessional things, one of which is the division of work and the involvement of personnel in an unbalanced team.

The phenomenon that researchers encountered during conducting this research was to find the condition of PR personnel who were considered to be seniors doing lighter tasks compared to younger and younger personnel. In the context of professionalism, a senior is considered as an experienced person, should get more weighty responsibilities than his juniors. In the context of PR, such showing as relatively young PR are considered more professional.

The next researcher connects the meaning of PR as a science and technology information manager. Science and Technology Information is information that contains information about the development of technological science, then also research programs for the development and engineering of the technology itself. Information limits that should be understood by GPR Officers working in research institutions should not be limited to product outputs by the organization. We must convey the development of world science and technology to the public. Because nuclear science and technology has a very specific region or scope, other knowledge may not need to be explained, there must be a chronology, there must be a comparison.

Based on the statement above, researchers assume that each PR Officer conveys information that is knowledgeable. Public Relations officials at research institutes deliver information about science and technology. Public Relations officials at a research institute manage science and technology information in accordance with the focus of the institution.

PR activities in government research institutes are activities that start from gathering information from leaders and researchers. Furthermore, selecting, selecting, processing, and packaging data into forms of information that are easily understood by the public. In communicating to the public, the use of the language style of PR must adjust the media / channel, for example in social media, internal media, books, curriculum forms, including when having to communicate to media reporters. PR Officers must master the material or basic knowledge of information published by the institution. This rticle interpreted that the PR Officer at the research institute must also have a lot of 'hooks' of information, aka information that is relevant to messages published by the institution. Thus, PR is interpreted as a provider of official, accurate, and reliable information.

After interviewing six informants from the Structural Public Relations Officer, the researcher then interviewed three Public Relations Functional Officers about the meaning of Public Relations for the Functional of PR Officer. The seventh informant in this study analogizes that PR is a funnel, it is a storefront for institutions, funnels for information, must 
know all the information available. PR is not only a firefighter, but also makes strategies so that the institution is trusted by the public, and builders of support from the community.

PR is a profession and must work professionally. All institutions need PR, including government research institutions. This opinion is quite reasonable if PR has been interpreted as a profession that must be undertaken with a professional. The meaning of PR in government research institutes is not merely an ordinary routine job. Do not let the PR in government research institutions do not feel the need to convey information about the results of research to the public because they think it is not their obligation.

Like it or not, PR in government research institutions need the support of these stakeholders to add more budget for research. PR in government research institutions are obliged to inform and communicate science and technology to the public, for the purpose of educating and gaining public trust. PR in government research institutions is needed so that the results of the research are communicated to the public. The goal, so that the public knows, the public understands, eventually the community becomes convinced that the taxes they pay to the State are used for useful allocations, namely research. Research will also be more advanced because of public support.

In interpreting PR, the following eight informants were unable to separate their experiences at the beginning when he joined the PR of a government research institute. At that time he felt that he had difficulty in learning the ins and outs of the tasks and functions of the institution. The informant's experience made him interpret PR as an administrative work unit.

His statement shows that he interpreted PR as a person who communicates. Tanti views communication as not a science that has to talk a lot, but must listen more and must be sympathetic to the person spoken to. Researchers argue that communication is a complex science, which studies the intra and interpersonal relationships, groups, organizations, the masses, and the public.

The meaning constructed by the ninth informant is through the assumption that PR is important because it is one of the advertisements, as a means for self-promotion. Researchers associate it with the term Personal Branding, where a GPR may compare himself as a PR who understands engineering, life, earth, social issues or certain other fields, according to the focus of the institution where he works. Behind the name of a PR person working in a government or private institution, the person automatically also carries the name of the institution. In addition to self-promotion, researchers assume that the term 'advertising' is also intended for another definition, namely the promotion of institutions. The definition also implies that PR in government research institutions is an information channel in the context of disseminating information on science and technology to stakeholders, in order to gain public trust.

\section{Discussion}

The researcher begins the discussion from the observations of the institution under study. Based on the researcher's analysis, the research institute under study has alluded to communication activities with the public in the broad goals of the institution, particularly in terms of service.

One of the missions of government research institutes, for instance, is to carry out dissemination of nuclear science and technology by emphasizing the principles of usefulness, safety and security, while one of the guidelines in the values held by government research institutes is Communicative. The mission is translated again into the mission, one of which is to improve information service provision through cooperation networks with various institutions and media. Good governance through bureaucratic reform is also carried out in 
order to realize technological innovation and services. One strategy is to improve human resources competencies in accordance with their fields of work through training, coaching, and education.

After obtaining the interview data from all informants, the researchers then categorized and typed. Almost all of the answers given by informants were to interpret GPR in research institutions as a work unit, not a profession. GPR in research institutions is a mouthpiece of positive information that cannot be separated from an organization and bureaucracy, is obliged to win public trust to get public support through marketing, promotion, public education, dissemination, and communicating research results, in order to advance the welfare of society. GPR also means as a mouthpiece and mouthpiece, including in providing input to the leadership.

'Humas' is a term of PR which used in Indonesia, often abbreviated as Public Relations (Gunawan, 1998). The definition of PR in Indonesia is similar to the definition of public relations in America. 'Humas' or PR, is an effort to create a harmonious and understanding relationship between an organization and its public. PR is an art and also a social science that has behavioral patterns and predicts their consequences, thus giving guidance to an organization's management in executing programs for the good of the organization and its public. [10]

However, Indonesian people have different perceptions in interpreting PR. Like the findings that the researchers compiled in the following table the meaning of GPR. The researcher presents the research findings data on the meaning of PR in the three government research institutions in the following table:

Table 1. The Meaning of PR in Government Research Institutes [11]

Institutions The Meanings

\begin{tabular}{|c|c|}
\hline $\begin{array}{l}\text { Research } \\
\text { institution } 1\end{array}$ & $\begin{array}{l}\text { Connector, Spokesperson, messenger from inside } \\
\text { out, Spokesman, Take the positive, always } \\
\text { bureaucratic, must know the official rules, Give } \\
\text { input to the leadership, make the image of the } \\
\text { institution more positive, People who talk a lot to } \\
\text { the public, Administrative work units }\end{array}$ \\
\hline $\begin{array}{l}\text { Research } \\
\text { Institution } 2\end{array}$ & $\begin{array}{l}\text { Inseparable from an organization, support the } \\
\text { institution, part of marketing, to increase PNBP, so } \\
\text { that the institution gets a higher trust from the } \\
\text { government, Don't look for higher profits, promote } \\
\text { the welfare of society, Realizing the ideals of } \\
\text { institutions and society, a means for promotion, } \\
\text { information channel }\end{array}$ \\
\hline $\begin{array}{l}\text { Research } \\
\text { Institution } 3\end{array}$ & $\begin{array}{l}\text { Public educator, information disseminator, convey } \\
\text { information that should be conveyed to the public, } \\
\text { funnel of an institution, information funnel, not } \\
\text { just being a fire extinguisher, communicator, make } \\
\text { strategies so that institutions are trusted by the } \\
\text { public, profession, not an ordinary routine job, } \\
\text { communicating the results of research to the public }\end{array}$ \\
\hline
\end{tabular}


The informants' answers are the informant's typification process, where the stock of knowledge they have influences the meaning they build. The meanings of PR in government research institutions are as spokespersons, administrative work units, promotion activities, information channels, public educators, and institutional mouthpieces.

In this study, public relations officials at government research institutes were divided in two. First, structural officials, and the other one is a functional public relations officer (named Pranata Humas). Structural officials of the GPR are interpreted as accompanying leaders, supporting institutions, part of marketing, public educators, dissemination, information delivery, mouthpieces for institutions, and spokespersons.

As by this research also be known that Pranata Humas interpreting themself in the government research institutions as an Institutional Communicator. It also appears that they prefer to interpret PR as a Subject or someone who acts, not as a work unit only.

Furthermore, the researchers looked at the concept initiated by Anwar Arifin Andipate, that the concept and activities of PR are far broader than just publicity or marketing and advertising. That is, information (publicity), marketing, and advertising are the only "one" form of activity in the current concept of PR. PR has broader activities, including conducting research, to know and understand the internal and external public. The results of the research are used to establish policies or revise existing policies (Gunawan, 1998) [12]. This concept is very relevant to the findings in research on the meaning of PR in the government research institutions as a strategy maker and communicator of research results. The focus that is the identity and characteristics of today's PR shows that they cannot be separated from communication, image, public opinion, research, management, and ethics (good intentions). [13]

\section{Conclusion}

PR interpret PR in the government research institutions as an educator and institutional communicator. Most of the informant's answers mention that the meaning of PR is as the person in charge of talking, forwarding information, translating the aspirations of the leadership, and conveying to stakeholders both internal and external. Following are the conclusions of research on the meaning of PR in the government research institutions:

\section{Conveying an Educational Message}

In general, the public already knows that PR as the person in charge of providing information to the public. The information conveyed by PR is basically educational messages, which enlighten public knowledge, and should be delivered to anticipate or overcome concerns about the emergence of negative issues.

\section{Science Communicators}

A PR interpreted before he communicates with the public. The messages that are communicated then need to be processed, translated, and delivered to the public in more popular and simpler languages so that they are easily received.

The PR ideally also acts as a translator regarding attitudes, policies, or management measures that have an impact on the public. The PR should also act as a mediator for public reaction to the management of the institution. The first thing a PR officer should pay attention to is management policy. Before they can draw attention, give understanding, and ideas are 
accepted, the PR must know what is the background, thoughts, and management considerations in making a decision / policy.

Diverse experiences and knowledge 'meet' in an atmosphere of interaction, then there is an exchange of meanings and the interaction unwittingly constructs a construction of meaning. The two meanings interpreted by the researcher, the PR as an educator and institutional communicator, indicate that the meaning of the PR is inseparable from interaction activities, where the purpose of the interaction is to create the same meaning. In fact, the interactions experienced by the PR have each subjective meaning. Knowledge, experience, and awareness are objective processes of subjective meaning processes. The formation of meaning by $\mathrm{PR}$ is supported by their experience and knowledge.

\section{References}

[1] Hakim, et al.: Jejak Humas Pemerintah, pp. 24-39. Direktorat Jenderal Informasi dan Komunikasi Publik, Indonesia (2013)

[2] Yulianita, Neni.: Dasar-dasar Public Relations, pp. 169. Bandung Islamic University, Indonesia (2012)

[3] Rachmawati, Dyah.: Construction Meaning of Government Public Relations for Structural and Functional (Phenomenology Study on the Meaning of Government Public Relations Officer in BATAN, BPPT, and LAPAN on Managing Information of Science and Technology), pp. 142-144. Padjadjaran University (2016)

[4] Rachmawati, Dyah.: Construction Meaning of Government Public Relations for Structural and Functional (Phenomenology Study on the Meaning of Government Public Relations Officer in BATAN, BPPT, and LAPAN on Managing Information of Science and Technology), pp. 145. Padjadjaran University (2016)

[5] Lattimore, Dan, Otis Baskin, Suzzete T. Heiman, Elizabeth L. Toth.: Public Relations Profesi dan Praktik, pp. 4. Salemba Humanika, Indonesia (2014)

[7] Creswell, John W.: Qualitative Inquiry and Research Design, pp. 32. Sage Publication, California (2014)

[8] Littlejohn, Stephen W.: Theories of Human Communication $7^{\text {th }}$ ed, pp. 166-167. Wadsworth, California (2002)

[10] Kriyantono, Rachmat.: Teknik Praktis Riset Komunikasi, pp. 351. Kencana Prenada Media, Indonesia (2014)

[11] Griffin, EM.: A firs Look at Communication Theory $7^{\text {th }}$ ed, pp. 99. McGraw Hill, USA (2012)

[12] Simorangkir, Deborah.: Public Relations in Indonesia History, Status, and Popular (Mis)perception. pp.11. Lambert Academy Publishing, USA (2009)

[13] Adopted from Rachmawati, Dyah.: Construction Meaning of Government Public Relations for Structural and Functional (Phenomenology Study on the Meaning of Government Public Relations Officer in BATAN, BPPT, and LAPAN on Managing Information of Science and Technology), pp. 268-269. Padjadjaran University (2016)

[14] Andipate, Anwar Arifin.: Paradigma Baru Public Relations Teori, Strategi, dan Riset, pp. 21. Pustaka Indonesia dan UPI YAI, Indonesia (2015)

[15] Andipate, Anwar Arifin.: Paradigma Baru Public Relations Teori, Strategi, dan Riset, pp. 26. Pustaka Indonesia dan UPI YAI, Indonesia (2015) 